Upon Opening the Black Box and Finding it Full: Exploring the Ethics in Design Practices

\author{
Marc Steen, marc.steen@tno.nl
}

Published in: Science, Technology, and Human Values, 40, 3 (2015), 389-420.

http://sth.sagepub.com/content/40/3/389

\begin{abstract}
Contemporary design practices, such as participatory design, human-centred design and co-design, have inherent ethical qualities, which often remain implicit and unexamined. Three design projects in the high-tech industry were studied using three ethical traditions as lenses. Virtue ethics helped to understand cooperation, curiosity, creativity and empowerment as virtues that people in participatory design need to cultivate, so that they can engage, for example, in mutual learning and collaborative prototyping. Ethics-of-alterity (Levinas and Derrida) helped to understand human-centred design as a fragile encounter between project-team members and prospective users, and foregrounds the ethics in these encounters: our tendencies to 'grasp the other' and to 'program invention.' And pragmatist ethics (Dewey) helped to understand co-design as a process of joint inquiry and imagination, involving the organization of iterative processes of problem-setting and solution-finding, with moral qualities. When we open the 'black boxes' of design practices, we find them filled with ethics. Moreover, it is proposed that design practitioners need to make explicit their practices' inherent ethical qualities and that they can do that by embracing reflexivity.
\end{abstract}

Keywords: Design, Ethics, Reflexivity

\title{
Introduction
}

What do we need to know about design? ${ }^{\mathrm{i}}$ What kind of knowledge do we need to have about the practices of designers, developers and engineers, who help to shape our world? In everyday life, we usually focus on the output of design processes; for example, when we interact with the digital devices or online services that were designed by these people-our smart phones, tablet computers or social networking services, for example. Or sometimes we focus on the input of design processes and are interested in the resources, time and budget that are needed in a design project. In this essay, however, I will focus on design processes, rather than on their output or input. 
Below, I will propose that contemporary design practices, such as participatory design, human-centred design and co-design, have inherent ethical qualities, which often remain implicit and unexamined. Furthermore, I will advocate making these ethics explicit so that the people involved can become more aware of these ethical qualities and can incorporate them consciously and reflexively in their practices. This can help them to realize more fully the transformative potential of design.

Finally, this essay also aims to further our understanding of design processes and their ethical qualities, enabling us-the people who use the products and services that result from them-to criticize and to participate more actively in these processes.

\section{Design and Ethics}

In 'Upon opening the black box and finding it empty' Langdon Winner (1993) expressed discontent with the lack of attention to moral questions in studies of the development or application of technology. He argued that, although these studies 'have opened the black box and shown us a colorful array of social actors, processes and images therein, the box they reveal is still a remarkably hollow one' (1993). At that time, many scholars were neglecting, ignoring or steering away from moral questions. In the twenty years since, there has been a growing interest in ethics in the field of STS, for example, in studies of the ethics of various design practices (e.g. Garrety and Badham 2004; Keulartz et al. 2004; Mitcham 1995; Shilton 2012; Van de Poel and Verbeek 2006; Verbeek 2005; Verbeek 2006).

One way to approach the relationship between design and ethics is Value Sensitive Design (VSD) (Friedman and Kahn 2003; cf. Albrechtslund 2007; Cummings 2006; Flanagan et al. 2008; Van de Poel 2009; Manders-Huits 2010). This approach argues that those involved in a design process attempt—intentionally or unintentionally-to embed specific values in the products or services that they develop (similar to the notion of scripts, Akrich 1992; 1995; cf. Allhutter 2012; Van der Velden and Mörtberg 2012).

VSD advocates organizing a process in which different stakeholders can express and negotiate their perspectives on these values in order to integrate these productively.

Another way to approach the relationship between design and ethics focuses on design as an social process (Bucciarelli 1994). Devon and Van de Poel, for example, argued that design is inherently a social activity and quintessentially an ethical process-'Ethics is not an appendage to design but an integral part of it' (Devon and Van de Poel 2004) —and advocated making these ethical qualities more explicit, for example, by examining 'the social 
arrangements for making decisions' and the 'iterative social process for making technical and social decisions'. It is this approach that I aim to contribute to with this essay.

Below I will study specific design projects and the social processes in these projects. The reason for focusing on the specific and the social follows from the character of design practices. They are always specific, in that they are concerned with developing specific solutions for specific problems, and always social, in that communication and cooperation are at the heart of design (Bucciarelli 1994; Devon 2004). This focus is in line with Van de Poel and Verbeek's (2006) proposal to 'perform a context-sensitive form of ethics,' that is, to study people's social practices within specific projects.

My studies are of project-teams involving 10 to 30 people, and their cooperation with each other and with prospective users, and stretch over the 2 to 3 year duration of the project. As a consequence, the 'black boxes' that I opened were much smaller than the larger systems, such as urban infrastructures, and their larger political and societal dimensions that concerned Winner $(1988 ; 1993)$.

\section{Design Practices}

Understanding people's daily life experiences and involving potential users in innovation or design projects are ways to increase the success of these projects (Cooper 1999; Van der Panne et al. 2003). Such approaches are especially relevant in developing of information and communication technology (ICT). They help to counter the risks of technology push, that is, the risk of starting with technology, rather than with people, which can easily lead to developing products or services that people cannot or do not want to use (Nielsen 1993; Norman 1988), which is typical for the ICT industry (Thackara 1999; 2006). The industry is therefore increasingly embracing approaches like participatory design (PD), human-centred design (HCD) or co-design.

These terms-PD, HCD and co-design-are often used loosely or interchangeably. These approaches involve potential or prospective users or customers (Kujala 2003; Rohracher 2005; Edvardsson et al. 2006) in product or service design processes, organize collaborative, creative and iterative processes (Cross 2006; Lawson 2006; Steen 2011b) and create products or services that match people's needs and preferences (Kujala 2003, Steen et al. 2011).

Below, however, I will bring their differences to the fore to argue that design practices have inherent ethical qualities. Moreover, I will propose three ethical traditions as perspectives to look at these ethical qualities. ${ }^{\text {ii }}$ 
I did not discover these ethical qualities. These ethical qualities were put into these design approaches by the people who pioneered and developed them. PD emerged from political/collective motives to empower people and to let them participate in the design process, and has gradually moved towards ethical/individual motives. Human-centred design attempts to focus on people in the high-tech industry, to facilitate user involvement and multidisciplinary teamwork. And co-design is concerned with organizing processes of collective creativity and with various practical methods to do that. This essay is an attempt to uncover-not discover-some of the ethics inherent in design practices.

\section{Participatory design}

Participatory design (PD) refers to a 'Scandinavian' approach to information systems design (Bjerknes et al. 1989; Bjerknes and Bratteteig 1995; Ehn 1990; Greenbaum and Kyng 1991; Kyng and Mathiassen 1997). PD has its roots in projects in the 1970s and 1980s in which researchers and developers cooperated with workers to promote workplace democracy and workers' empowerment so that 'the people destined to use the system play a critical role in designing it' (Schuler and Namioka 1993, xi). These roots still resonate, for example, in a sensitivity to power differences and agency, but its political motives and collective action ('carrying out an action programme to give the weak parties knowledge they can use to increase their power'), have shifted towards ethical motives and individual action ('the quest for democracy was left to the individual system developer' and his or her 'individual ethical codex') (Bjerknes and Bratteteig 1995).

Therefore, I propose that studying the ethical qualities of contemporary PD will require a perspective that focuses on the thoughts, feelings and actions of individuals. The tradition of virtue ethics provides such a perspective. Below, I will explore and discuss virtues related to collaboration, curiosity, creativity and empowerment that are needed by people who work in PD projects.

\section{Human-centred design}

Various approaches can be grouped under the heading of human-centred design ${ }^{\mathrm{iii}}$ (HCD); what they share are four principles (ISO 1999; cf. Steen 2011b): the active involvement of potential 'users' throughout the project; the search for an appropriate balance of functions between people and technology; the organization of an iterative process of research, design and evaluation; and the organization of multi-disciplinary teamwork. HCD typically involves interviews or workshops in which project-team members and 'users' interact. HCD can vary 
in its level of human-centred-ness; for example, a superficial type of HCD would invite 'users' near the end of a project to evaluate prototypes that were developed with a minimum of input from 'users', whereas a more thorough type of HCD would involve 'users' early-on, for example, in creative workshops, in which project-team members and users jointly articulate a problem and explore solutions.

My discussion of HCD will focus on the encounters between project-team members and 'users', and on project-team members' attempts to combine their own ideas with the ideas of 'users', and to make progress, to draw conclusions and deliver results. I will look at these attempts through the perspective of ethics-of-alterity and discuss the difficulties of these fragile, face-to-face encounters and their inherent ethical qualities.

\section{Co-design}

The term co-design ${ }^{\text {iv }}$ refers to 'collective creativity as it is applied across the whole span of a design process' (Sanders and Stappers 2008). One might argue that all design is co-design, since design practices are always social practices (Bucciarelli 1994). Co-design typically refers to the organizing of collaborative creativity and is sometimes used synonymously to PD. In comparison to HCD, co-design can tend more towards creative and generative activities, inviting, for example, 'users' to participate in workshops for joint brainstorming and fantasizing, sketching and storytelling or tinkering with all sorts of mock-ups or prototypes (Sanders 2000; Sanders and Stappers 2008). For example, context mapping (Sleeswijk Visser et al. 2005; Sleeswijk Visser 2009) is associated with co-design; in this method, researchers and designers conduct observations and interviews in the daily life contexts of 'users' and use their findings to inform and inspire their design process.

Co-design is typically seen as a pragmatic approach to facilitate collaboration and creativity. I will therefore look at co-design through the perspective of philosophical pragmatism, which similarly aims to bring together people so that they can jointly effect positive change. I will focus my discussion of co-design on organizing collaborative and creative processes-on organizing a project's iterative cycles of problem-setting and solution-finding.

\section{Applications in the ICT industry}

Although the three approaches discussed have their origins in the ICT industry, they are not (yet) widely applied there. Many innovation projects in the ICT industry focus on technology, rarely involve users, and often have a rather homogeneous project-team, representing, for 
example, technology and business concerns, and a rather linear process, going from specification to development to implementation. Studies in the ICT industry revealed that 'usability and user involvement [have] low priority' (Gulliksen et al. 2004), that user involvement 'is often difficult and rare' (Iivari 2006), that only 'less than one percent' (Venturi and Troost 2004) of employees interact with 'users', and that efforts are needed to make such approaches 'part of the business strategy and endorsed by higher management' (Venturi et al. 2006).

Some of the elements from PD, HCD or co-design are, however, applied in the ICT industry, for example, in the form of usability engineering (Nielsen 1993), contextual design (Beyer and Holzblatt 1998), or agile software development.

\section{Methodology}

This essay is based on studies of design practices in three projects: WeCare, FRUX and TA2 (details below). These projects share a concern for developing and evaluating ICT applications and services, and an approach that organized multidisciplinary team work and interactions with potential users, for example, in observations, interviews, creative workshops, user tests and trials.

This research approach can be positioned in the tradition of laboratory studies (Latour and Woolgar 1986; Knorr Cetina 1995; Rip 2000; Woolgar 1991). My role can be described as participant observer-or maybe better, as observant practitioner, because of my intimate involvement in the practices studied (cf. Woolgar 1988; Ashmore 1989; Ellis and Bochner 2000). My primary role was to work in these projects, as a team member in research, design and coordination roles. My secondary role was to study these projects. This combination of practice and analysis can be traced back to Bijker's (1993) advocacy for practitioners to reflect on their practices: to start from practices, to embark on an 'academic detour' and then to 'turn to practice' to make the research findings practically applicable.

Below, I will discuss various design practices, looking through the lenses of different ethical traditions and drawing from the studies of these three projects: I will discuss PD through the lens of virtue ethics, and focus on several virtues that people need in PD, drawing from the WeCare project; I will discuss HCD through the lens of ethics-of-alterity and focus on face-to-face encounters, drawing from the FRUX project; and I will discuss co-design through the lens of pragmatist ethics and focus on organizing collaborative and creative processes, drawing from the TA2 project. $^{\mathrm{v}}$ 
I select these three ethical traditions because they are typically focused on specific and social practices, as do design practices. Virtue ethics focuses on people in specific, concrete and social contexts and their personal thoughts, feelings and actions in these situations. Ethics-of-alterity views people as inherently social beings, arguing that one always finds oneself in specific and concrete relationships. And pragmatist ethics takes people's practices and experiences as a starting point for analysis and aims to deliver practical results. The lens through which we look thus matches the phenomena we observe.

Another argument for this selection is that these three ethical traditions are more suitable than the more mainstream deontological or consequentialist traditions, which focus on finding or applying general rules, based on one's moral duties or on the consequences of one's actions respectively. Moreover, deontological or consequentialist approaches would typically focus on the inputs (duties) or on the outputs (consequence) of design processes, whereas we are currently interested in the processes themselves.

\section{Participatory Design and the Virtues of Cooperation, Curiosity, Creativity and Empowerment}

The project studied as an example of participatory design (PD) was the WeCare project (part of the European Ambient Assisted Living research programme). This project focused on improving older people's wellbeing by enabling them to engage in online social networking, thereby promoting social interaction and participation in social networks, both online and 'in real life'. The project consortium included industry partners (e.g. a supplier of high-quality online video communication), care or service providers (e.g. a provider of tele-care services for people in rural areas), organizations that represent older people and their interests, and research organizations in four countries: Finland, Spain, Ireland and The Netherlands. For each country, a PD process was organized that involved older people and people in their social networks - such as family and friends-in the design and evaluation of four online social networking services, one for each country. This approach enabled the project-team members to match the services to the needs and usage contexts of different groups of older people.

The services were developed as prototypes and evaluated in user trials, and included applications for social communication, such as video communication and discussion forums, 
and for coordinating social activities, such as shared calendars and ways to request or offer support between participants.

\section{Virtue Ethics}

For my discussion of PD, I draw from virtue ethics; an ethical tradition that focuses on cultivating virtues and enabling people to flourish (eudaimonia). Virtue ethics is teleological in that it starts with an ultimate goal (telos): the goal for people to flourish, to live the good life. Virtues are 'dispositions not only to act in particular ways, but also to feel in particular ways. To act virtuously ... is to act from inclination formed by the cultivation of virtues' (MacIntyre 2007, 149).

In virtue ethics, one aims for an appropriate middle between deficiency and excess, given the specific circumstances. For example, the virtue of courage would be an appropriate middle between cowardice and recklessness, and would play out differently for different people in different circumstances. Finding this middle 'requires therefore a capacity to judge and to do the right thing in the right place at the right time in the right way' (MacIntyre 2007, 150). It must be noted that finding this middle is concerned with striving for excellence (arete), with doing something very well, not with mediocrity or moderation, and with cultivating well-formed types of natural desires (MacIntyre 2007, 160), not with countering desires. One can learn to think, feel and act virtuously by trying-out virtuous behaviours or by looking at people who behave virtuously.

I would like to propose that promoting cooperation, collaborative curiosity, collaborative creativity, and empowerment can be understood as key virtues that are needed in PD. In the spirit of virtue ethics-which is concerned with specific people in concrete situations (Pritchard 1998) - these virtues will be illustrated with examples from the WeCare project (for details: Steen et al. 2012b; Steen 2013b; Steen et al. in press).

\section{Promoting Cooperation}

Cooperation is at the core of PD (Bjerknes and Bratteteig 1995; Bratteteig and Stolterman 1997; Kensing and Blomberg 1998). In PD cooperation is promoted with care, patience and attention for group dynamics, so that the people involved can engage in cooperative curiosity and cooperative creativity (see below). One will aim for a middle between the deficiency of neglecting the subtleties of group dynamics and cooperation, and the excess of controlling people and forcing them to cooperate. This virtue is especially needed in people in management or leadership roles. 
The interventions of the project manager of the WeCare project, Sharon, illustrate the virtue of promoting cooperation. Every couple of months, she organized project-team meetings, with people from different countries and different organizations. Usually, in such meetings, people left their laptop computers open and combine attending the meeting with working on their laptop, such as answering email. Sharon, being aware of what is needed to promote cooperation, asked people to close their laptops and to pay full attention to the meeting and to the other people. In addition, she organized relatively long lunch breaks, with a walk in a nearby park or a visit to a restaurant, to encourage project-team members to socialize and relax. Sharon understood that one needs to invest in such activities in order to promote cooperation. Such interventions helped project-team members to collaborate effectively throughout the project.

\section{Cooperative Curiosity}

The virtue of cooperative curiosity is a disposition of being open and receptive towards other people and their experiences, and towards one's own experiences and learning. Typical methods to promote curiosity in PD are mutual learning (Bødker et al. 1987; Bjerknes and Bratteteig 1987) or ethnography (Blomberg et al. 1993; Button 2000).

Mutual learning was pioneered in the Utopia project, in which system developers cooperated with graphic workers to develop and evaluate information systems to support workers (Bødker et al. 1987). The developers and the workers had diverse meetings in which the developers learned about the workers' ways of working, their skills and their usage of tools, and in which the workers learned about (at that time) new technologies, such as computer displays and printers. Based on this mutual learning, they were able to jointly develop mock-ups and prototypes (see below). Another approach to foster curiosity is to draw from the tradition of ethnography, for example, by conducting all sorts of fieldwork to inform or inspire the design process. Ethnography can help one to focus on other people, rather than on one's own ideas about these people (Blomberg et al. 1993).

In PD one needs to find a middle between the deficiency of too little sensitivity to other people's or one's own experiences, and the excess of too much receptiveness to other people's or one's own experiences.

Jannie's actions may exemplify the virtue of cooperative curiosity. Jannie worked for an organization that represents older people and their interests, and her role in the project was to promote a better understanding of older people's behaviours and needs. In several meetings, she noticed that people tend to use stereotypes when talking about older people. An 
unsubstantiated utterance like 'older people find it hard to use computers' makes it easy to stay within one's own frame of reference. In order to counter that tendency, Jannie invited others to find out what older people actually $d o$ with computers, for example, by organizing co-design workshops in which project-team members and older people met and exchanged knowledge and ideas, which helped to promote empathy and cooperative curiosity.

\section{Cooperative Creativity}

The virtue of cooperative creativity is a disposition of jointly generating ideas, combining ideas of different people, and practically realizing products or services. Typical methods to promote creativity in PD are Future Workshops-in which people engage in three collaborative and creative phases: Critique, of the current situation; Fantasy, about more desirable alternatives; and Implementation, articulating short-term actions (Kensing and Madsen 1991)—or cooperative prototyping (Bødker et al. 1987; Ehn and Kyng 1991).

Cooperative prototyping - the hands-on creation and evaluation of mock-ups and prototypes-was also pioneered in the Utopia project (Ehn and Kyng 1991; Bødker et al. 1987). In that project, mock-ups were sometimes as simple as an empty cardboard box with the text 'laser printer' written on it. Using such mock-ups encouraged 'user involvement beyond the detached reflection that traditional systems descriptions allow'; 'everybody has the competence to modify them; they are cheap, hence many experiments can be conducted without big investments in equipment, commitment, time, and other resources' (Ehn and Kyng 1991, 172-173).

In $\mathrm{PD}$, one needs to find a middle between the deficiency of too little attention for other people's or one's own ideas, and the excess of too much realization of other people's or one's own ideas.

Stefan's role illustrates the virtue of collaborative creativity. Stefan was responsible for coordinating technology development; he coordinated different project partners' activities of developing and combining software modules into working prototypes. Technology development became critical when organizing user trials, in which these prototypes were going to be used by people in their daily lives. In one meeting, it became clear that specific modules were not delivered on schedule and did not meet the 'user requirements'. Often, such a situation makes people focus on their own role and on looking backward, making up excuses and trying to blame others-which is not very productive for finding a solution. Instead, Stefan stayed calm and invited people to talk constructively with each other, to look 
ahead and to explore and develop practical solutions, which helped to promote cooperative creativity.

\section{Empowerment}

In PD one also needs the virtue of empowerment: the disposition to share power and agency with others $^{\mathrm{vi}}$, also with people outside the project, for example, the people who are supposed to be going to benefit from the project's results. One can do that by aiming for a middle between the deficiency of being passive and hesitant, for example, assuming that people will cope and thrive without help, and the excess of being patronizing and directive, for example, assuming that people will prosper if only they follow your advice. In the PD tradition, the tool perspective has been key to empower workers: 'The idea is that new computer-based tools should be designed as an extension of the traditional practical understanding of tools and materials used within a given craft or profession' (Ehn 1993, 57). The tool perspective respects people's tacit knowledge and skills, and enables them to contribute to the development of the tools which they will be using. Moreover, it advocates developing tools that people can use actively and creatively, thus empowering them, rather than developing finished products that can only be used in predetermined and fixed ways, with the risk of making their users passive and disempowering them.

The virtue of empowerment can be illustrated with an example of John Thackara (1999), at that time project manager of the Presence project, which aimed to develop user-friendly Internet services for older people (similar to the WeCare project). This is what he wrote about the project-team members' first encounter with their 'target group':

Someone said, "There are a lot of older people out there; let's see if we can find some and help them by giving them this Internet stuff in an easy-to-use format". So we went and found some older people and told them how we had come to help them with the Internet, and they said, "Piss off! [...] We don't need your patronising help, you designers. If you've come here to help us, you're wasting your time; we don't want to be helped, thanks just the same. Yet we do have some interesting observations to make about our daily lives, about our lifestyles, about our communication, and about all of their attendant dysfunctions. If you could kindly change your attitude and help us explore how we will live, then perhaps we can do something together"

Rather than creating a product and then bringing it to 'users', one needs to share power and agency with 'users' so that they can become active participants and creative contributors, 
rather than passive receivers, so that they can jointly create tools that people can use actively and creatively.

In sum, we can understand PD as a praxis in which the people involved need to cultivate the virtues of promoting cooperation, of collaborative curiosity and collaborative creativity, and of empowerment, sharing power and agency with others.

\section{Human-Centred Design as a Fragile Encounter}

The project studied as an example of human-centred design (HCD) was the FRUX project (part of the Dutch BSIK research programme). This project aimed to develop two innovative mobile telecom services for two user groups, and to organize the design process in close cooperation with them: one for and with police officers, and another for and with informal care-givers. The projects combined technology push (to develop telecom services), and an HCD approach (to cooperate with prospective 'users').

The project-team members organized observations, interviews, workshops and field trials with 'users', and designed and evaluated two prototypes, one for each target group: a mobile telecom service that helps different types of police officers to share information and to collaborate while they are out on the street, and an online social networking service that helps people to communicate and coordinate informal care for people with dementia, for example, sharing care and other tasks between family members who jointly provide care for one of their (grand)parents.

There were project-team members with their experiences, knowledge and ideas to develop telecom services. And there were 'users', with their experiences, knowledge and ideas about their daily lives. The project attempted to bring these people together in face-to-face interactions.

\section{Ethics-of-Alterity}

I looked at HCD through the lens of ethics-of-alterity ${ }^{v i i}$, a type of ethics that takes the other and the relationships between other and self as a starting point, with Emmanuel Levinas (1906-1995) and Jacques Derrida (1930-2004) as key proponents. Levinas wrote extensively about the encounter between other and self, and Derrida about différance and otherness ${ }^{\text {viii }}$. In their ethics-of-alterity one always finds oneself within other-self relationships, which are inherently ethical relationships. 
In a HCD project, people attempt to communicate and cooperate-which Levinas and Derrida would conceive of as encounters between other and self and as ethical situations. Let me attempt to deconstruct (cf. Derrida 1991) two key assumptions of HCD as a way to bring the ethical qualities of HCD to the fore, based on readings of Levinas and Derrida (for details: Steen 2008; Steen 2012).

\section{Developing Knowledge and the Tendency to Grasp the Other}

A key assumption in HCD is that project-team members can jointly learn new things-that they can gather and develop new knowledge, for example, about prospective users and their needs and preferences. It can be hard, however, for project-team members, to be open towards others and to learn new things, for example, when they interact with prospective users in interviews or workshops.

Throughout his oeuvre, Levinas was concerned with the difficulties of encounters between people and with the violence that so often occurs in these encounters. He argued that one tends to not see the other as other, but as an object, and to reduce the other to concepts that one is already familiar with: 'The foreign being ... becomes a theme and an object. ... It falls into the network of a priori ideas, which I bring to bear, as to capture it' (Levinas 1987, 48, 50). He characterized this tendency as the making of a grasping gesture. One pulls the other into one's own way of thinking: 'knowledge remains linked to ... the grasp' (Levinas 1996b, 152). Levinas described the self, 'the I of knowledge', as a 'melting pot where every Other is transmuted into the Same' (Levinas 1996a, 13). In an attempt to develop knowledge, the self grasps the other, which makes it very difficult to learn anything new.

HCD practitioners cannot escape this tendency. Their interests and ambitions, their knowledge and ideas - their selves - get in the way of their attempts to be open towards other people and their interests, ambitions, knowledge and ideas.

In the FRUX project, for example, we conducted a series of four creative workshops with different groups of police officers. Based on the findings from each workshop, we gradually changed our project's focus and developed a mobile telecom application that promotes cooperation between police officers. It does so by automatically making suggestions to share 'implicit knowledge' between police offices. In HCD, such learning, based on interactions with users, is considered good practice.

Nevertheless, we also missed several opportunities to learn from police officers and to let their ideas influence our project. In our interactions with police officers, we often privileged our own ideas. In the first workshop, for example, we jointly explored four areas that the 
police officers experienced as problematic. After the workshop, however, we chose to focus on the one area that was comfortably close to our ambition to develop an innovative telecom application. Consequently, we ignored other areas that were relevant to the police officers, such as their problems with their current systems for sharing and accessing information, or their struggles with their professional roles and with the police's organizational culture.

In order to counter this tendency to 'grasp the other,' Levinas envisioned an attempt to escape the gesture of grasping via a form of desire that is not aimed at satisfying the self and is respectful of the otherness of the other: 'This desire without satisfaction hence takes cognizance of the alterity of the other' (Levinas 1987, 56).

\section{Making Decisions and the Tendency to Program Innovation}

Another key assumption in HCD is that the people involved can organize iterative phases of divergence, of research and exploration, towards openness, and of phases of convergence, of evaluation and drawing conclusions, that is, towards closure. Project-team members not only need to be open towards others and to explore; they also need to draw conclusions and to deliver results- to create closure and to make progress.

Regarding the process of decision making, Derrida remarked that genuine decisions are 'exceptional': 'a decision that does not make an exception, that does nothing but repeat or apply the rule, would not be a decision' (Derrida 2001, 29), and that a genuine decision cannot be made by merely applying knowledge or following rules. A decision that is based on knowledge is 'an application, a programming' (Derrida 1995, 147-8). Similarly, Derrida observed that people often attempt to program innovation and argued that this can lead to 'the invention of the same' (Derrida 1989, 46, 55).

Because of this tendency to program innovation, one tends to stay within one's own comfort zone, which makes it hard to create anything new. In HCD, project-team members cannot escape this tendency. They bring their own backgrounds and methods to the encounters with other people, and these influence the balance between openness and closure-typically more towards closure.

In the FRUX project, for example, we also cooperated with 'primary' informal caregivers: people who provide 'primary' informal care to people who suffer from dementia and who live at home, often their husband or wife. Different project-team members followed different approaches to talk with them about their daily lives and their needs.

Some project-team members, who were familiar with dementia and informal care and who had social science backgrounds, conducted a questionnaire-based survey with hundreds of 
people with dementia and their 'primary' informal caregivers. In parallel, other project-team members, for whom dementia and informal care were relatively new areas, and who worked in design roles, conducted informal interviews to inspire their creative process.

Both approaches were attempts to move toward openness, to learn from other people about their daily lives. However, they were also moves toward closure-to draw conclusions about other people's needs and creating products for them. The people doing the survey used a standardized questionnaire, so responses had to match its categories. The people doing the design-interviews wanted to create an innovative telecom application and were looking for inspiration, which influenced their interviews. Both groups brought their methods to the encounters with others as a way to focus and to move towards closure.

To escape these tendencies towards closure and programming, Derrida advocated welcoming the other: "To invent would then be to "know" how to say "come" and to answer the "come" of the other' (Derrida 1989, 56). This would be an active form of passivity because it requires an effort to not make the other into a theme within one's own program.

In sum, we can see HCD as a fragile, face-to-face encounter between people, involving attempts to develop knowledge and being open towards others (and to counter the tendency to grasp the other), and attempts to make decisions and progress and to balance openness and closure (and to counter the tendency to program innovation).

\section{Co-design as a Process of Joint Inquiry and Imagination}

The project studied as an example of co-design was the TA2 project (part of the European 7th Framework Program). Approximately 40 researchers, designers and developers, with different backgrounds, such as technology, business and social science, from 14 organizations, ranging from international corporations and small enterprises to universities and research institutes, collaborated in this project. The project's goals were to develop and evaluate a series of innovative telecommunication, multimedia and gaming applications, and to better understand how such technologies can help groups of people to engage in social communication when they are separated in space and in time, so that they can experience togetherness- 'TA2' stands for Together Anywhere, Together Anytime.

The project delivered a series of prototypes for different target groups and usage contexts: Space Explorers, a game that combines TV-based video communication and a board game, which groups of friends can play from different locations; Sixth Age, a series of casual games 
for TV or tablet computer, which, for example, grandparents can play with their grandchildren, facilitating also social communication; Jump Style: a video communication and editing application, which, for example, teenagers can use to create and share video clips while practicing dance moves; MyVideos, an application for creating and sharing video compilations of an event, for example, a school concert, based on footage shot by various people; and Connected Lobby, a TV-based social networking service that helps people to initiate social communication by sharing status updates.

The project manager facilitated a co-design process in which diverse project-team members collaborated with each other and with people from different target groups, involving various methods: interviews in people's homes at the start of the project, to learn about their daily lives; creative workshops and discussions of ideas in iterative cycles throughout the project, to explore, discuss and improve ideas; and evaluations of prototypes, further-on in the project, both in the lab and in people's daily lives (for details: Steen 2013a; Steen et al. 2012a; Steen et al. 2014).

\section{Pragmatist Ethics}

I turned to philosophical pragmatism to discuss the process of co-design. Pragmatism emerged in the USA in the late 19th century, with key figures such as William James, C.S. Peirce and John Dewey. Below, I will focus on texts by Dewey (1859-1952) because his perspective is relevant indeed to discussions of technology (Hickman 1990), engineering (Emison 2004) and design (Melles 2008; Dalsgaard 2009). A key theme in his work was the productive combination of practice and theory, and his advocacy for an empirical method of moving back and forth between practices (primary experiences) and reflections (secondary experiences) (Dewey 1965, 36). In contrast to mainstream views on science as a search for universal knowledge, Dewey contended that knowledge is always provisional, particular and contingent rather than universal and necessary (Dewey 1920, 78). Another key theme in Dewey's work was his meliorism: 'the belief that the specific conditions which exist at one moment, be they comparatively bad or comparatively good, in any event may be bettered' (Dewey 1920, 178) and his advocacy for cooperation and empowerment. His concerns for practical experiences and for promoting positive change converged in his ideas concerning inquiry (Hickman 1998), which forms the basis for the current discussion.

Dewey envisioned a process of joint inquiry and imagination in which people can better understand their current situations, imagine more desirable situations, and develop ways to cooperate in their realization, so that they move from a situation of 'perplexity' towards a 
resolution: 'Inquiry is the controlled or directed transformation of an indeterminate situation into ... a unified whole' (Dewey 1938, 104-105).

Co-design can be understood as a very similar process, involving collaborative design thinking (Dorst 2011) and organizing collaborative problem-setting and solution-finding (Lawson 2006, 125; Cross 2006, 80).

Dewey saw inquiry and imagination as processes with inherent ethical qualities. Moral experiences were his starting point, and empowering people to cope with moral questions was his primary goal (Stuhr 1998, 85). Similarly, co-design can be understood as a process of 'moral inquiry' which proceeds 'by dialogue, visualization, imagining of motor responses, and imagining how others might react to a deed done' (Hildebrand 2008, 77; cf. Lloyd 2008).

Dewey conceptualized this process of inquiry and imagination as consisting of different phases (Dewey 1938, 101-119), which are ideally organized as an iterative process, moving from problem exploration and definition, via perceiving the problem and conceiving of possible solutions, to trying out and evaluating solutions.

\section{Problem Exploration and Definition}

At first, people experience a specific situation as problematic, without yet knowing what is precisely problematic about it. Dewey stressed that personal and subjective experiences are critical for the start of an inquiry process, to make the situation questionable. Expressing and sharing these experiences are critical: 'inquiry is not a purely logical process-feeling is a useful and orienting presence throughout each phase' (Hildebrand 2008, 57). A provisional problem definition is formulated, which can later be restated and refined.

The ethics of co-design are enacted when participants express their experiences and empathize with others. In the TA2 project, for example, several co-design workshops were organized in order to facilitate problem exploration and definition. Three months into the project a Scenario Workshop was organized in which key team members were invited to empathize with specific groups of people and to take them, and their experiences, as starting points for developing five scenarios: short narratives of people using the TA2 applications. Another example was a Togetherness Workshop, in the tenth month of the project, in which team members were invited to engage more personally, and morally, with the theme of togetherness, and the project's goal to promote togetherness. Such workshops helped projectteam members to ground the project's problem definition in specific and moral experiences. 
In an iterative process, the problem and possible solutions are simultaneously explored and developed (Dewey 1938, 109). Dewey proposed that problems are best explored using perception, one's capacities to see, hear, touch, smell and taste, and that solutions are best developed using conception, one's capacities to imagine and envision alternative situations.

The ethics of co-design occur, for example, when participants use their capacities for perception and engage with visualizations of the problem (Sleeswijk Visser 2009), or when they use their capacities for conception and engage in creative activities (Sanders 2000). Ideally, co-design participants can imagine or rehearse current (problematic) situations or alternative (desirable) situations (cf. 'moral imagination' or 'dramatic rehearsal' in Fesmire 2003, 55-91).

In TA2 this process was facilitated by creating and discussing five storyboards: for each of the TA2 applications a series of five to ten drawings with accompanying narratives. These storyboards were developed, based on the findings from the Scenario Workshop, in an iterative process between key project-team members and a professional illustrator. Creating these storyboards helped the people involved to discuss how the project's overall goal and ideas for specific solutions relate to each other. Moreover, the storyboards were discussed in a series of focus groups with different groups of people, which helped the project-team members to improve their ideas, based on a better understanding of different people's daily lives, needs, expectations and preferences.

Creating and discussing these storyboards brought to the fore the ethics of co-design in that project-team members and users were able to jointly perceive a problem, for example, the current lack of togetherness, to jointly conceive of possible solutions, for example, a specific feature in one of the TA2 applications, and to move between perception and conception, for example, when project-team members listened to users talking about their problems and modified their prototypes accordingly.

\section{Trying-out and Evaluating Solutions}

In order to find out which solutions 'work', different possible solutions are tried-out and evaluated, for example, in practical experiments. The project becomes more real and the stakes get higher. It may become clear, for example, that different participants or stakeholders have different interests. In such cases, the people involved need to negotiate carefully in order to bring the project to successful completion. They will need to find ways to combine their interests productively, in order to deal with even 'deep-seated and fundamental value conflicts' (Keulartz et al. 2004) and develop solutions that 'work' for all of them. 
The ethics of co-design occur when the people involved are able to jointly achieve concrete results and critically evaluate these results, and when they are able to productively negotiate and combine their different interests.

In TA2 this process involved the development and evaluation of several prototypes, in cooperation with potential users, in laboratory experiments and in field trials in people's homes. The project-team members working on MyVideos, for example, cooperated with two groups of parents with children in two high schools. One group of (Dutch) parents made video recordings of a school concert in which their children performed, and evaluated a first prototype of MyVideos while viewing and editing the video material of that concert. They also participated in discussions about options for further development, which helped to steer the development of a second prototype. Another group of (British) parents made video recordings of a school concert and participated in user tests with this second prototype.

In sum, we can understand co-design as a process of joint inquiry and imagination, involving perception in problem-setting and conception in solution-finding-a process in which people are enabled to use 'the power of intelligence to imagine a future which is the projection of the desirable in the present, and to invent the instrumentalities of its realization' (Dewey 1917, 69).

\section{Summary}

I explored the ethical qualities of participatory design (PD), human-centred design (HCD) and co-design practices, using different ethical perspectives to look at different aspects of the design process:

Virtue ethics helped to understand the dispositions of people who work in PD projects and to argue that they need virtues related to cooperation, curiosity, creativity and empowerment. Ideally, they can cultivate these virtues, so that their thoughts, feelings and actions develop in a way that helps them to engage in, for example, mutual learning or collaborative prototyping.

Ethics-of-alterity helped to understand the ethical qualities of face-to-face encounters between people in $\mathrm{HCD}$, for example, between team members and 'users', in interviews or workshops. Ideally, they become aware of these ethics, so that they can interact more 
consciously and are able to better find balances between other and self, and between openness and closure.

A pragmatist perspective helped to look at the ethics of organizing a co-design process: a collaborative and creative process of problem-setting and solution-finding. Ideally, the project is managed in such a manner that the people involved can engage in a process of joint inquiry and imagination, for example, by organizing the project in iterative cycles of research, design and evaluation.

Table 1. Ethical qualities inherent in design practices

\begin{tabular}{l|ccc}
\hline \multicolumn{1}{c|}{ Perspective } & Virtue ethics & Ethics-of-alterity & Pragmatist ethics \\
\hline \multicolumn{1}{c}{ Focus } & $\begin{array}{c}\text { Participants' feelings, } \\
\text { thoughts, actions }\end{array}$ & $\begin{array}{c}\text { Face-to-face encounters } \\
\text { and interactions }\end{array}$ & $\begin{array}{c}\text { Managing a project and } \\
\text { its iterative cycles }\end{array}$ \\
\hline $\begin{array}{l}\text { Cooperation as } \\
\text { the basis }\end{array}$ & $\begin{array}{c}\text { Promoting cooperation } \\
\text { and empowerment }\end{array}$ & $\begin{array}{c}\text { Encounters between } \\
\text { other and self }\end{array}$ & $\begin{array}{c}\text { Process of collaborative } \\
\text { design thinking }\end{array}$ \\
\hline $\begin{array}{l}\text { An inwards- } \\
\text { directed move }\end{array}$ & $\begin{array}{c}\text { Cooperative curiosity: } \\
\text { openness, empathy } \\
\text { and joint learning }\end{array}$ & $\begin{array}{c}\text { Developing knowledge: } \\
\text { being open to the other } \\
\text { (not grasp the other) }\end{array}$ & $\begin{array}{c}\text { Joint inquiry: perception, } \\
\text { empathy and problem- } \\
\text { setting }\end{array}$ \\
\hline $\begin{array}{l}\text { An outwards- } \\
\text { directed move }\end{array}$ & $\begin{array}{c}\text { Cooperative creativity: } \\
\text { developing, realizing } \\
\text { and trying-out ideas }\end{array}$ & $\begin{array}{c}\text { Making decisions: } \\
\text { balancing openness and } \\
\text { closure (not program) }\end{array}$ & $\begin{array}{c}\text { Joint imagination: } \\
\text { conception, creativity } \\
\text { and solution-finding }\end{array}$ \\
\hline
\end{tabular}

One may notice several recurring themes in these discussions of design practices: they are based on cooperation between diverse people, and they involve inwards-directed moves and an outward-directed moves in the people involved—see Table 1.

Design practices are based on cooperation between different people: on the virtue of promoting cooperation and the virtue of empowerment, of sharing power and agency with others; on face-to-face encounters between diverse people, for example, between projectteam members and potential 'users'; and on organizing collaborative problem-setting and solution-finding.

Participants need to allow for an inwards-directed move, from other people and the world outside towards themselves: when they engage in cooperative curiosity, involving openness, empathy and joint learning; when they develop knowledge, and attempt to be open to other people; and when they engage in joint inquiry and use their capacities for perception and empathy in problem-setting.

Additionally, they need to allow for an outward-directed move, from themselves towards other people and the world outside: when they engage in cooperative creativity, involving the 
development, realization and trying-out of ideas and possible solutions; when they make decisions, and attempt to balance openness and closure; and when they engage in joint imagination and use their capacities for conception and creativity in solution-finding.

Moreover, these ethical perspectives complement one another and highlight different elements of design practices: individual participants' feelings, thoughts and actions; face-toface encounters and interactions; and management of a project and its iterative cycles. Taken together, they constitute a proposal — a middle range theory (Wyatt 2007) — to understand the ethics that are inherent in contemporary design practices.

\section{Reflexivity in Design}

Finally, I would like to propose that people in PD, HCD or co-design projects need to make these ethical qualities (more) explicit. These ethical qualities are there anyway and influence their practices anyway, either negatively (for instance, when they experience misunderstandings, frictions or conflicts) or positively (for instance, when they experience the joy of interacting and cooperating with others, of learning and creating.) In both cases, it would be productive when participants can cope with these inherent ethics more explicitly and consciously. Making these ethics explicit can help them to more fully realize the transformative potential of design.

Design—and especially approaches like PD, HCD or co-design—can help to cope with various societal challenges, ranging from health and education to safety and sustainability (Papanek 1991; Nelson and Stolterman 2003; Thackara 2006; Burns et al. 2006), to propose and develop practical solutions, and to create products and services that help people to live meaningful and fulfilling lives (Nieusma 2004; Oosterlaken 2009; Van de Poel 2012; Desmet 2013). The potential of design is to make innovation projects more participatory, more human-centred and more co-creative. Design may thus help to solve some of the problems that it has in the past contributed to-such as creating a world that is focused on consumption and on gadgets: 'If we can design our way into difficulty, we can design our way out' (Thackara 2006, 1).

Moreover, I propose that people involved in innovation and design projects can make these ethics explicit by embracing reflexivity. Reflexivity can help them to become more aware of their dispositions, their ways of thinking and feeling and acting (virtue ethics), of the moves they make between other and self, and between openness and closure (ethics-of- 
alterity), and of the ethical qualities of organizing collaboration and creativity (pragmatist ethics).

The term reflexivity refers here to a type of reflection on practices in which one is actively involved, and on one's own involvement in these practices (cf. Weick 2002; Steen 2011a) ${ }^{\text {ix }}$. Such reflexivity in the people involved in design practices $^{\mathrm{x}}$ would help them to reflect critically and creatively on their own practices and to modify their practices in more appropriate or desirable directions - to 're-design' design practices.

Similarly, Stovall saw reflexivity, or 'professional self-awareness' $(2011,110)$, as 'a sort of master virtue that fosters the reflective deliberation necessary for a professional to pursue their work in an aspirational frame of mind' (2011, 125). Such reflexivity involves 'examining critically the assumptions underlying our actions [and] the impact of those actions', which can help to 'develop more collaborative, responsive, and ethical ways of managing organizations (Cunliffe 2004; cf. Hibbert et al. 2010; Orr and Bennett 2009). In a very similar vein, Rhodes (2009) proposed an 'ethical response to reflexivity ... that asks questions rather than provides answers; that refuses the hubris of generalizations; that provokes thinking rather than provides answers; that generates possibilities rather than prescriptions; that seeks openness rather than closure'.

Those involved in innovation and design projects—such as myself—could, for example, ask questions like the following: What is happening here and now? How am I moving between other and self, between openness and closure? How are we using our capacities for perception, our capacities for conception? How is the cooperation process evolving? Am I promoting curiosity, or creativity? Are we sharing power and agency? What do I think and feel? What do I want to do? What can I do differently? ${ }^{x i}$

\section{Acknowledgements}

The studies on which this paper is based were conducted in three projects: FRUX, which received funding from the Dutch Ministry of Economic Affairs under contract BSIK 03025; TA2, which received funding from the European Community's Seventh Framework Programme (FP7/2007-2013) under grant no. ICT-2007-214793; and WeCare, which received funding in the European Ambient Assisted Living Joint Programme (AAL-2009-2026). I would like to thank my employer TNO and the managers of these projects for facilitating me to conduct these studies: Edward Faber of FRUX, Doug Williams of TA2 and Sharon Prins of WeCare. Furthermore, I would like to thank my fellow project-team members for their kind permission to study and write about our projects. Moreover, I would like to thank the people who helped me in earlier works on which the current paper is based: Hugo Letiche and Jan Buijs (for Steen 2008); Pieter Jan Stappers and Ilpo Koskinen (for Steen 2012); Larry Hickman (for Steen 2013b); and Paul van Tongeren (for Steen 2013a). 


\section{References}

Akrich, M. 1992. The de-scription of technical objects. In Shaping technology / Building society: Studies in sociotechnical change (pp. 205-224), eds W. E. Bijker and J. Law. Cambridge, Massachusetts and London, England: MIT Press.

Akrich, M. 1995. User representations: Practices, methods and sociology. In Managing technology in society (pp. 167-184), eds A. Rip, T. J. Misa and J. Schot. London and New York: Pinter Publishers.

Albrechtslund, A. 2007. Ethics and technology design. Ethics and Information Technology 9 (1): 63-72.

Allhutter, D. 2012. Mind scripting: A method for deconstructive design. Science, Technology, \& Human Values 37 (6): 684-707.

Ashmore, M. 1989. The reflexive thesis: Wrighting sociology of scientific knowledge. Chicago and London: The University of Chicago Press.

Beyer, H., and K. Holzblatt. 1998. Contextual design: Defining customer-centred systems. San Fransisco, California: Morgan Kaufmann.

Bijker, W. E. 1993. Do not despair: There is life after constructivism. Science, Technology, \& Human Values 18 (1): 113-138.

Bjerknes, G., and T. Bratteteig. 1987. Florence in Wonderland: System development with nurses. In Computers and democracy: A Scandinavian challenge (pp. 279-296), eds G. Bjerknes, P. Ehn and M. Kyng. Aldershot: Avebury.

Bjerknes, G., and T. Bratteteig. 1995. User participation and democracy: A discussion of Scandinavian research on system development. Scandinavian Journal of Information Systems 7 (1): 73-98.

Bjerknes G., P. Ehn, and M. Kyng. 1989. Computers and democracy: A Scandinavian challenge. Aldershot: Avebury.

Blomberg, J., J. Giacomi, A. Mosher, and P. Swenton-Hall. 1993. Ethnographic field methods and their relation to design. In Participatory design: Principles and practices (pp. 123-155), eds D. Schuler and A. Namioka. Hillsdale, NJ: Lawrence Erlbaum.

Bødker, S., P. Ehn, J. Kammersgaard, M. Kyng, and Y. Sundblad. 1987. A Utopian experience: On design of powerful computer-based tools for skilled graphic workers. In Computers and democracy: A Scandinavian challenge (pp. 251-278), eds G. Bjerknes, P. Ehn and M. Kyng. Aldershot: Avebury.

Bratteteig, T., and E. Stolterman. 1997. Design in groups--and all that jazz. In Computers and design in context (pp. 289-315), eds M. Kyng and L. Mathiassen. Cambridge, MA: MIT Press.

Bucciarelli, L. 1994. Designing engineers. Cambridge, MA: MIT Press.

Buchanan, R. 2001. Human dignity and human rights: Thought on the principles of human-centered design. Design Issues 17 (3): 35-39.

Burns, C., H. Cottam, C. Vanstone, and J. Winhall. 2006. Transformation Design. London: Design Council.

Button, G. 2000. The ethnographic tradition and design. Design Studies 21 (4): 319-332.

Chesbrough, H. W. 2003. Open innovation: The new imperative for creating and profiting from new technology. Boston, Massachusetts: Harvard Business School Press.

Cooper, A. 1999. The inmates are running the asylum: Why high-tech products drive us crazy and how to restore the sanity. Indianapolis, Indiana: SAMS Publishing.

Critchley, S. 1999. The ethics of deconstruction: Derrida and Levinas (2nd ed.). Edinburgh: Edinburgh University Press.

Cross, N. 2006. Designerly ways of knowing. London: Springer-Verlag.

Cummings, M. L. 2006. Integrating ethics in design through the value-sensitive design approach. Science and Engineering Ethics 12 (4): 701-715.

Cunliffe, A. L. 2004. On becoming a critically reflexive practitioner. Journal of Management Education 28 (4): 407-426.

Dalsgaard, P. 2009. Designing engaging interactive environments: A pragmatist perspective (PhD dissertation). Aarhus: Aarhus Unversity.

Derrida, J. 1989. Psyche: Inventions of the Other (Translated by Catherine Porter). In Reading de Man Reading (pp. 25-64), eds L. Waters and W. Godzich. Minneapolis, Minnesota: University of Minnesota Press.

Derrida, J. 1991. From "Différance" in Margins of Philosophy [original 1972] (Translated by Alan Bass). In A Derrida reader: Between the blinds (pp. 59-79), ed P. Kamuf. New York: Columbia University Press.

Derrida, J. 1991. Letter to a Japanese friend [original 1987]. In A Derrida reader: Between the blinds (pp. 270276), ed P. Kamuf. New York: Columbia University Press.

Derrida, J. 1995. Dialanguages. In Points... Interviews, 1974-1994 (pp. 132-155). Stanford, California: Stanford University Press.

Derrida, J. 2001. Deconstructions: The Im-possible. In French Theory in America (pp. 12-32), eds S. Lotringer and S. Cohen. New York and London: Routledge. 
Desmet, P. 2013. Positive design (inaugural lecture). Delft: Delft University of Technology.

Devon, R. 2004. Towards a social ethics of technology: A research prospect. Techne: Research in Philosophy and Technology 8 (1): 99-115.

Devon, R., and I. Van de Poel. 2004. Design ethics: The social ethics paradigm. International Journal of Engineering Education 20 (3): 461-469.

Dewey, J. 1917. The need for a recovery of philosophy. In Creative intelligence: Essays in the pragmatic attitude (pp. 3-69), ed J. Dewey. New York: Henry Holt and Co.

Dewey, J. 1920. Reconstruction in philosophy. New York: Henry Holt and Co.

Dewey, J. 1938. Logic: The theory of inquiry. New York: Henry Holt and Co.

Dewey, J. 1965. Experience and nature. La Salle, Illinois: Open Court Publishing.

Dorst, K. 2011. The core of 'design thinking' and its application. Design Studies 32 (6): 521-532.

Dunne, T., and F. Raby. 2001. Design noir: The secret life of electronic objects. Basel, Boston.

Edvardsson B., A. Gustafsson, P. Kristensson, P. Magnusson, and J. Matthing. 2006. Involving customers in new service development. London: Imperial College Press.

Ehn, P. 1990. Work-oriented design of computer artifacts. Hillsdale, NJ: Lawrence Erlbaum Associates.

Ehn, P. 1993. Scandinavian design: On participation and skill. In Participatory design: Principles and practices (pp. 41-77), eds D. Schuler and A. Namioka. Hillsdale, New Jersey: Lawrence Erlbaum.

Ehn, P., and M. Kyng. 1991. Cardboard computers: Mocking-it-up or hands-on the future. In Design at work: Cooperative design of computer systems (pp. 169-196), eds J. Greenbaum and M. Kyng. Hillsdale, NJ: Lawrence Erlbaum Associates.

Ellis, C., and H. R. Bochner. 2000. Autoethnography, personal narrative, reflexivity: Researcher as subject. In Handbook of qualitative research (2nd edition) (pp. 733-768), eds N. K. Denzin and Y. S. Lincoln. Sage: Thousand Oaks, London, New Delhi.

Emison, G. A. 2004. American pragmatism as a guide for professional ethical conduct for engineers. Science and Engineering Ethics 10 (2): 225-233.

Fesmire, S. 2003. John Dewey and moral imagination: Pragmatism in ethics. Bloomington, IN: Indiana University Press.

Flanagan, M., D. C. Howe, and H. Nissenbaum. 2008. Embodying values in technology: Theory and practice. In Information technology and moral philosophy (pp. 322-353), eds J. Van den Hoven and J. Weckert. Cambridge: Cambridge University Press.

Friedman, B., and P. Kahn. 2003. Human values, ethics, and design. In The human-computer interaction handbook: Fundamentals, evolving technologies and emerging applications (pp. 1177-1201), eds J. Jacko and A. Sears. Mahwah, NJ: Lawrence Erlbaum Associates.

Garrety, K., and R. Badham. 2004. User-centred design and the normative politics technology. Science, Technology, \& Human Values 29 (2): 191-212.

Greenbaum J., and M. Kyng. 1991. Design at work: Cooperative design of computer systems. Hillsdale, NJ: Lawrence Erlbaum Associates.

Gulliksen, J., I. Boivie, J. Persson, A. Hektor, and L. Herulf. 2004. Making a difference: a survey of the usability profession in Sweden. In Proceedings of NordiCHI, the third Nordic conference on humancomputer interaction (pp. 207-215), ed A. Hyrskykari. New York: ACM.

Hibbert, P., C. Coupland, and R. MacIntosh. 2010. Reflexivity: Recursion and relationality in organizational research processes. Qualitative Research in Organizations and Management 5 (1): 47-62.

Hickman, L. A. 1990. John Dewey's pragmatic technology. Bloomington and Indianapolis: Indiana University Press.

Hickman, L. A. 1998. Dewey's theory of inquiry. In Reading Dewey: Interpretations for a postmodern generation (pp. 166-186), ed L. A. Hickman. Bloomington and Indianapolis: Indiana University Press.

Hildebrand, D. 2008. Dewey: A beginner's guide. Oxford: Oneworld Publications.

Iivari, N. 2006. Exploring the rhetoric on representing the user -- Discourses on user involvement in academia and the IT artifact product development industry. International Journal of Technology and Human Interaction 2 (4): 54-81.

ISO. 1999. ISO 13407: Human-Centred Design Processes for Interactive Systems. Geneva, Switzerland: ISO.

Jordan, P. W. 2002. Human factors for pleasure seekers. In Design and the social sciences: Making connections (pp. 9-23), ed J. Frascara. Taylor \& Francis.

Kensing, F., and J. Blomberg. 1998. Participatory design: Issues and concerns. Computer Supported Cooperative Work 7 (3-4): 167-185.

Kensing, F., and K. H. Madsen. 1991. Generating visions: Future Workshops and metaphorical design. In Design at work: Cooperative design of computer systems (pp. 155-168), eds J. Greenbaum and M. Kyng. Hillsdale, NJ: Lawrence Erlbaum Associates.

Keulartz, J., M. Schermer, M. Korthals, and T. Swierstra. 2004. Ethics in technological culture: A programmatic proposal for a pragmatist approach. Science, Technology, \& Human Values 29 (1): 3-29. 
Knorr Cetina, K. 1995. Laboratory studies: The cultural approach to the study of science. In Handbook of Science and Technology Studies (pp. 140-166), eds S. Jasanoff, G. E. Markle, J. C. Petersen and T. Pinch. London: Sage.

Kujala, S. 2003. User involvement: A review of the benefits and challenges. Behaviour and Information Technology 22 (1): 1-16.

Kyng M., and L. Mathiassen. 1997. Computers and design in context. Cambridge, MA: MIT Press.

Latour, B., and S. Woolgar. 1986. Laboratory life: The construction of scientific facts (2nd ed.). Princeton, New Jersey: Princeton University Press.

Lawson, B. 2006. How designers think: The design process demystified (4th ed.). Amsterdam: Elsevier.

Levinas, E. 1987. Philosophy and the idea of infinity (Translated by Alphonso Lingis) [original 1957]. In Collected philosophical papers (pp. 47-59). Dordrecht: Martinus Nijhoff Publishers.

Levinas, E. 1996a. Transcendence and height [original 1962]. In Emmanuel Levinas: Basic philosophical writings (pp. 11-32), eds A. Peperzak, S. Critchley and R. Bernasconi. Bloomington and Indianapolis: Indiana University Press.

Levinas, E. 1996b. Transcendence and intelligibility [original 1984]. In Emmanuel Levinas: Basic philosophical writings (pp. 149-159), eds A. Peperzak, S. Critchley and R. Bernasconi. Bloomington and Indianapolis: Indiana University Press.

Lloyd, P. 2008. Ethical imagination and design. Design Studies 30 (2): 154-168.

MacIntyre, A. 2007. After virtue (3rd ed.). London: Duckworth.

Manders-Huits, N. 2010. What values in design? The challenge of incorporating moral values into design. Science and Engineering Ethics 17 (2): 271-287.

Melles, G. 2008. New Pragmatism and the Vocabulary and Metaphors of Scholarly Design Research. Design Issues 24 (4): 88-101.

Mitcham, C. 1995. Ethics into design. In Discovering design (pp. 173-189), eds R. Buchanan and V. Margolin. Chicago and London: The University of Chicago Press.

Nelson, H. G., and E. Stolterman. 2003. The design way: Intentional change in an unpredictable world. Englewood Cliffs, New Jersey: Educational Technology Publications.

Nielsen, J. 1993. Usability Engineering. London: Academic Press.

Nieusma, D. 2004. Alternative design scholarship: Working toward appropriate design. Design Issues 20 (3): 13-24.

Norman, D. A. 1988. The psychology of everyday things. New York, NY: Basic Books.

Oosterlaken, I. 2009. Design for development: A Capability Approach. Design Issues 25 (4): 91-102.

Oosterlaken, I. 2013. Taking a capability approach to technology and its design. Delft: Delft University of Technology.

Oosterlaken, I., and J. Van der Hoven. 2012. The capability approach, technology and design. Dordrecht: Springer.

Orr, K., and M. Bennett. 2009. Reflexivity in the co-production of academic-practitioner research. Qualitative Research in Organizations and Management 4 (1): 85-102.

Papanek, V. 1991. Design for the real world (2nd ed.). London: Thames \& Hudson.

Pritchard, M. S. 1998. Professional responsibility: Focusing on the exemplary. Science and Engineering Ethics 4 (2): 215-233.

Rhodes, C. 2009. After reflexivity: Ethics, freedom and the writing of organzation studies. Organization Studies 30 (6): 653-672.

Rip, A. 2000. There's no turn like the empirical turn. In The empirical turn in the philosophy of technology (Volume 20) (pp. 3-17), eds C. Mitcham, P. Kroes and A. Meijers. Elsevier Science.

Rohracher H. 2005. User involvement in innovation processes: Strategies and limitations from a socio-technical perspective. München, Germany and Wien, Austria: Profil Verlag.

Sanders, E. B. N. 2000. Generative Tools for Co-designing. In Collaborative Design: Proceedings of CoDesigning 2000 (pp. 3-12), eds S. A. R. Scrivener, L. J. Ball and A. Woodcock. London: Springer-Verlag.

Sanders, E. B. N., and P. J. Stappers. 2008. Co-creation and the new landscapes of design. CoDesign 4 (1): 5-18.

Schuler D., and A. Namioka. 1993. Participatory design: Principles and practices. Hillsdale, New Jersey: Lawrence Erlbaum Associates.

Sen, A. 1999. Development as freedom. New York: Knopf.

Sengers, P., K. Boehner, S. David, and J. '. Kay. 2005. Reflective design. In Proceedings of the 4th decennial conference on Critical computing: between sense and sensibility (pp. 49-58), eds O. W. Bertelsen, N. O. Bouvin, P. G. Krogh and M. Kyng.

Shilton, K. 2012. Values levers: Building ethics into design. Science, Technology, \& Human Values 38 (3): $374-$ 397.

Sleeswijk Visser, F. 2009. Bringing the everyday life of people into design [doctoral dissertation]. Delft: Delft University of Technology. 
Sleeswijk Visser, F., P. J. Stappers, R. Van der Lugt, and E. B. N. Sanders. 2005. Contextmapping: Experiences from practice. CoDesign 1 (2): 119-149.

Steen, M. 2008. The fragility of human-centred design [doctoral thesis].: Delft University of Technology.

Steen, M. 2011a. Reflexive practice in human-centred design. Zoontechnica 1 (1).

Steen, M. 2011b. Tensions in human-centred design. CoDesign 7 (1): 45-60.

Steen, M. 2012. Human-centred design as a fragile encounter. Design Issues 28 (1): 72-80.

Steen, M. 2013a. Co-design as a process of joint inquiry and imagination. Design Issues 29 (2): 16-29.

Steen, M. 2013b. Virtues in participatory design: Cooperation, curiosity, creativity, empowerment and reflexivity. Science and Engineering Ethics 19 (3): 945-962.

Steen, M., F. Berkers, and D. Williams. 2012a. TA2 Project Deliverable D8.10 Lessons learned and visions.: TA2 Project Consortium.

Steen, M., C. Broekman, and S. Prins. 2012b. WeCare Project Deliverable D1.4 Reflections on user involvement and co-design.: WeCare Project Consortium.

Steen, M., J. Buijs, and D. Williams. 2014. The role of scenarios and demonstrators in promoting shared understanding in innovation projects. International Journal of Innovation and Technology Management.

Steen, M., M. Ervasti, M. Harjumaa, S. Bourke, V. Hernandez, M. Min, and S. Prins. In press. WeCare: Cooperating with older people in the design and evaluation of online social neworking services. In Ambient Assisted Living, eds N. M. Garcia, J. J. P. C. Rodriges, D. C. Elias and M. S. Dias. Taylor and Francis.

Steen, M., M. Manschot, and N. de Koning. 2011. Benefits of co-design in service design projects. International Journal of Design 5 (2): 53-60.

Stovall, P. 2011. Professional virtue and professional self-awareness: A case study in engineering ethics. Science and Engineering Ethics 17 (1): 109-132.

Stuhr, J. J. 1998. Dewey's social and political philosophy. In Reading Dewey (pp. 82-99), ed L. A. Hickman. Bloomington and Indianapolis: Indiana University Press.

Thackara, J. 1999. An unusual expedition (Preface). In Presence: New media for older people (pp. 7-9), eds K. Hofmeester and E. De Charon de Saint Germain. Amsterdam: Netherlands Design Institute.

Thackara, J. 2006. In the bubble: Designing in a complex world. Cambridge, Massachusetts and London, England: MIT Press.

Van de Poel, I. 2009. Values in engineering design. In Handbook of the philosophy of science. Volume 9: Philosophy of technology and engineering (pp. 973-1006), ed A. Meijers. Elsevier.

Van de Poel, I. 2012. Can we design for well-being? In The good life in a technological age (pp. 295-306), eds P. Brey, A. Briggle and E. Spence. Routledge.

Van de Poel, I., and P.-P. Verbeek. 2006. Ethics and engineering design. Science, Technology, \& Human Values 31 (3): 223-236.

Van der Panne, G., C. Van Beers, and A. Kleinknecht. 2003. Success and failure of innovation: A literature review. International Journal of Innovation Management 7 (3): 309-338.

Van der Velden, M., and C. Mörtberg. 2012. Between need and desire: Exploring strategies for gendering design. Science, Technology, \& Human Values 37 (6): 663-683.

Venturi, G., and J. Troost. 2004. Survey on the UCD integration in the industry. In Proceedings of NordiCHI'04, the third Nordic conference on human-computer interaction (pp. 449-452), ed A. Hyrskykari. New York: ACM.

Venturi, G., J. Troost, and T. Jokela. 2006. People, organizations, and processes: An inquiry into the adoption of user-centered design in Industry. International Journal of Human-Computer Interaction 21 (2): 219-238.

Verbeek, P. P. 2005. What things do: Philosphical reflections on technology, agency, and design. University Park: Pennsylvania State University Press.

Verbeek, P. P. 2006. Materializing morality: Design ethics and technological mediation. Science, Technology, \& Human Values 31 (3): 361-380.

Weick, K. 2002. Real-time reflexivity: Prods to reflection. Organization Studies 23 (6): 893-898.

Winner, L. 1988. Do artifacts have politics? In The whale and the reactor: A search for limits in an age of high technology (pp. 19-39). University of Chicago Press.

Winner, L. 1993. Upon opening the black box and finding it empty: Social constructivism and the philosophy of technology. Science, Technology, \& Human Values 18 (3): 362-378.

Woolgar, S. 1988. Knowledge and reflexivity: New frontiers in the sociology of knowledge. London: Sage.

Woolgar, S. 1991. The turn to technology in social studies of science. Science, Technology, \& Human Values 16 (1): $20-50$.

Wyatt, S. 2007. Home on the range: What and where is the middle in science and technology studies? Science, Technology, \& Human Values 32 (6): 619-626. 
${ }^{i}$ This first sentence and the title allude, of course, to Langdon Winner's 1993 article.

ii This mapping—of three design approaches onto ethical perspectives—is somewhat arbitrary. One could have made other choices. Moreover, my argument will focus on the differences between design approaches and between ethical traditions, rather than on the many similarities and overlaps. Nevertheless, I will agree, for example, that people in HCD or co-design also need to cultivate specific virtues (probably virtues similar to the ones discussed in the context PD, below), or that encounters between people can also be studied via virtue ethics or pragmatist ethics (and not only via ethics-of-alterity, as will be done below), etcetera.

iii The term human-centered design is used here, rather than the term user-centered design because the latter tends to focus on a person in her role of 'user': 'The problem with usability-based approaches is that they encourage a limited view of the person using the product. This is - by implication if not by intentiondehumanizing' (Jordan 2002, 12; cf. Buchanan 2001). This concern is expressed, in this essay, by adding quotation marks to the word 'user'.

${ }^{\text {iv }}$ The term co-design is used, rather than the broader term co-creation, which refers to 'any act of collective creativity, i.e., creativity that is shared by two or more people' (Sanders and Stappers 2008). Furthermore, the terms co-design and co-creation can also be used to refer to collaboration between organizations, for example, in open innovation (Chesbrough 2003).

${ }^{\vee}$ This mapping—of ethical perspectives and onto specific projects—occurred for practical reasons at the time of conducting the studies on which the current essay is based. One could, of course, have used other projects as case studies and as examples of PD, HCD and co-design.

${ }^{\mathrm{vi}}$ Empowerment has been discussed more thoroughly in, for example, the Capability Approach, in the context of empowering people to expand their capabilities, so that they can effectively 'lead the kind of lives they have reason to value' (Sen 1999, 10; cf. Oosterlaken and Van der Hoven 2012; Oosterlaken 2013).

vii This term, ethics-of-alterity, was proposed by Simon Critchley to refer to the philosophies of Levinas and Derrida, in an email conversation (16 February 2012) (cf. Critchley 1999).

viii For a discussion of Levinas's use of 'autre/Autre' ('other') and 'autrui/Autrui' ('Other'), see Critchley 1999, 8. For a discussion of Derrida's use of 'différance', see Derrida 1991, 59-79.

${ }^{\text {ix }}$ This type of reflexivity, in which practitioners reflect on their own practices and their involvement in these practices, is similar to a type of reflexivity that researchers need when they are involved in the practices that they study (cf. Ashmore 1989, Woolgar 1988, Ellis and Bochner 2000).

${ }^{\mathrm{x}}$ This reflexivity in designers is different from a reflexivity in users that some designers aim to promote via 'reflective design'. In such a case, designers may create a product that encourages users to reflect on their values when interacting with this product (Sengers et al. 2005; Dunne and Raby 2001).

${ }^{x i}$ It is with such questions that I have returned back to the practice of innovation and design projects (cf. Bijker 1993). 